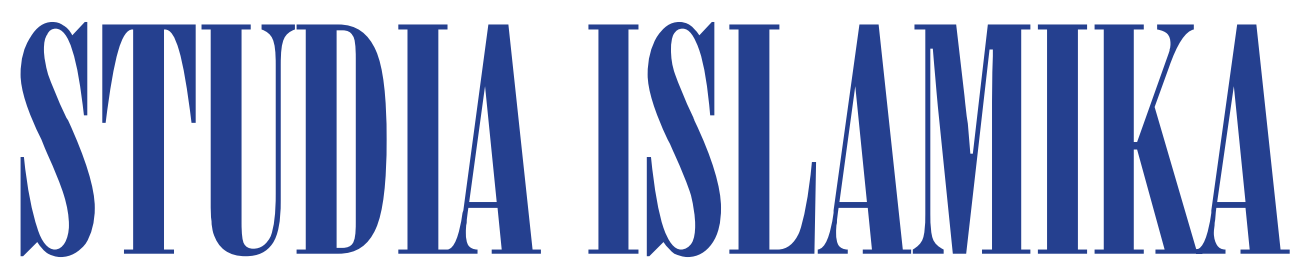

INDONESIAN JOURNAL FOR ISLAMIC STUDIES

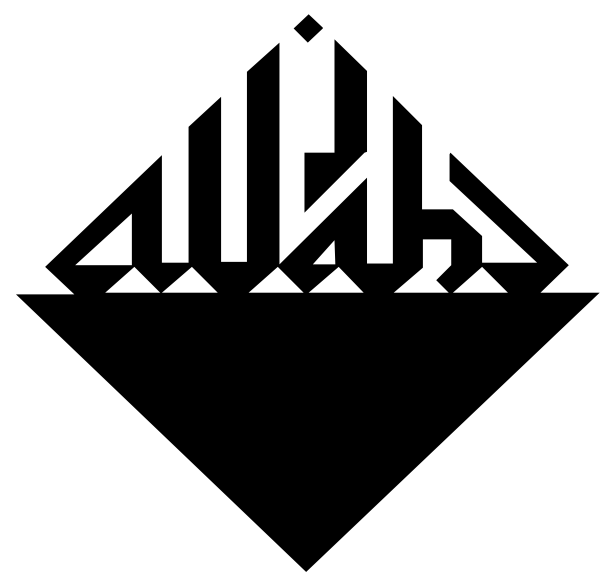

When Islamism and Pop Culture Meet:

A Political Framing of the Movie

212: THE POWER OF LOVE

Wahyudi Akmaliah

Islamic Identity and Foreign Policy Discourse:

INDONESIA'S RESPONSES TO THE US WAR

IN Afghanistan (200 I-2002)

Agus Salim

A Hadhrami Scholar and Islamic Court in Aceh:

The Political Biography of

'ABd AL-RahMĀN AL-Z̄̄ĀHIR (I 864-I878)

Mehmet Özay 
STIUDLA ISLAMIIIKA 



\section{STIDIIA ISLAVIIIKA}

Indonesian Journal for Islamic Studies

Vol. 27, no. 1, 2020

EDITOR-IN-CHIEF

Azyumardi Azra

MANAGING EDITOR

Oman Fathurahman

EDITORS

Saiful Mujani

Jambari

Didin Syafruddin

Jajat Burhanudin

Fuad Jabali

Ali Munhanif

Saiful Umam

Dadi Darmadi

Jajang Jahroni

Din Wahid

Euis Nurlaelawati

INTERNATIONAL EDITORIAL BOARD

M. Quraish Shihab (Syarif Hidayatullah State Islamic University of Jakarta, INDONESIA)

Martin van Bruinessen (Utrecht University, NETHERLANDS)

John R. Bowen (Washington University, USA)

M. Kamal Hasan (International Islamic University, MALAYSIA)

Virginia M. Hooker (Australian National University, AUSTRALIA)

Edwin P. Wieringa (Universität zu Köln, GERMANY)

Robert W. Hefner (Boston University, USA)

Rémy Madinier (Centre national de la recherche scientifique (CNRS), FRANCE)

R. Michael Feener (National University of Singapore, SINGAPORE)

Michael F. Laffan (Princeton University, USA)

Minako Sakai (The University of New South Wales, AUSTRALIA)

Annabel Teh Gallop (The British Library, UK)

Syafaatun Almirzanah (Sunan Kalijaga State Islamic University of Yogyakarta, INDONESIA)

ASSISTANT TO THE EDITORS

Testriono

Muhammad Nida' Fadlan

Rangga Eka Saputra

Abdullah Maulani

ENGLISH LANGUAGE ADVISOR

Benjamin J. Freeman

Daniel Peterson

Batool Moussa

ARABIC LANGUAGE ADVISOR

Tb. Ade Asnawi

Ahmadi Usman

COVER DESIGNER

S. Prinka 
STUDIA ISLAMIKA (ISSN 0215-0492; E-ISSN: 2355-6145) is an international journal published by the Center for the Study of Islam and Society (PPIM) Syarif Hidayatullah State Islamic University of Jakarta, INDONESIA. It specializes in Indonesian Islamic studies in particular, and Southeast Asian Islamic studies in general, and is intended to communicate original researches and current issues on the subject. This journal warmly welcomes contributions from scholars of related disciplines. All submitted papers are subject to double-blind review process.

STUDIA ISLAMIKA has been accredited by The Ministry of Research, Technology, and Higher Education, Republic of Indonesia as an academic journal (Decree No. 32a/E/KPT/2017).

STUDIA ISLAMIKA has become a CrossRef Member since year 2014. Therefore, all articles published by STUDIA ISLAMIKA will have unique Digital Object Identifier (DOI) number.

STUDIA ISLAMIKA is indexed in Scopus since 30 May 2015.

Editorial Office:

STUDIA ISLAMIKA, Gedung Pusat Pengkajian

Islam dan Masyarakat (PPIM) UIN Jakarta,

Jl. Kertamukti No. 5, Pisangan Barat, Cirendeu,

Ciputat 15419, Jakarta, Indonesia.

Phone: (62-21) 7423543, 7499272, Fax: (62-21) 7408633;

E-mail: studia.islamika@uinjkt.ac.id

Website: http://journal.uinjkt.ac.id/index.php/studia-islamika

Annual subscription rates from outside Indonesia, institution: US\$ 75,00 and the cost of a single copy is US\$ 25,00; individual: US\$ 50,00 and the cost of a single copy is US\$ 20,00 . Rates do not include international postage and handling.

Please make all payment through bank transfer to: PPIM, Bank Mandiri KCP Tangerang Graha Karnos, Indonesia, account No. 101-00-0514550-1 (USD),

Swift Code: bmriidja

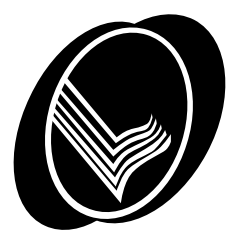

Harga berlangganan di Indonesia untuk satu tahun, lembaga: Rp. 150.000,-, harga satu edisi Rp. 50.000,-; individu: Rp. 100.000,-, harga satu edisi Rp. 40.000,-. Harga belum termasuk ongkos kirim.

Pembayaran melalui PPIM, Bank Mandiri KCP Tangerang Graha Karnos, No. Rek: 128-00-0105080-3 


\section{Table of Contents}

\section{Articles}

1 Wahyudi Akmaliah

When Islamism and Pop Culture Meet:

A Political Framing of the Movie

212: The Power of Love

35 Agus Salim

Islamic Identity and Foreign Policy Discourse:

Indonesia's Responses to the US War

in Afghanistan (2001-2002)

73 Mehmet $\ddot{O}_{z a y}$

A Hadhrami Scholar and Islamic Court in Aceh:

The Political Biography of

'Abd al-Raḥmān al-Zāhir (1864-1878)

103 Zainal Arifin Madzkur

Al-Rasm al-'Uthmānī

fī al-Muṣhaf al-mi'yārī al-Indūnīsī

'inda al-Dānī wa Abī Dāwud

145 Muhammad Amin Nurdin, Herdi Sahrasad, \& Smith Alhadar Al-Tawatturāt bayn al-Sunnah wa al-Shīah fī Maluku al-Shamālīyah: Durūs min al-Māḍi 


\section{Book Review}

177 Dadi Darmadi

Benang Merah dan Jalan Berbeda:

Pendidikan Agama Islam di Indonesia dan Malaysia

\section{Document}

195 Endi Aulia Garadian

In the Foot Step of Consolidating Ummah:

Highlights from the $7^{\text {th }}$ Indonesian Muslim Congress 


\title{
Mehmet Özay
}

\section{A Hadhrami Scholar and Islamic Court in Aceh: The Political Biography of 'Abd al-Rahmān al-Zāhir (1864-1878)}

\begin{abstract}
Abd al-Raḅmān al-Zähir (1833-1896) was an influential, dynamic Hadhrami. He was a Muslim reformer, as well as a savvy businessman and formidable diplomat. Arriving in Aceh in 1864, he embarked on both business and political endeavors, as religious and trade experiences helped develop diplomatic ties between the locals, the Ottomans, and the European powers. Although he surrendered in 1878 to the Dutch, his activities and infuence were increasingly common subjects for different colonial newspapers until the middle of the 20th century. This article reexamines al-Zähir's political role and his various interactions with Acehnese royal contends. It investigates his interactions with the Aceh court, the uleebalang, and the Dutch, as well as the socio-political environment that informed his surrender to the Dutch. Through investigations of numerous Ottoman, Dutch and indigenous sources, this article offers a glimpse into the reality of the indigenous responses to the decisions of this most trusted Hadhrami.
\end{abstract}

Keywords: 'Abd al-Raḥmān al-Zāhir, Aceh, Dutch War, Perang Sabil, İstanbul, Ottomans. 
Abstrak: 'Abd al-Rahmān al-Zāhir (1833-1896) adalah sosok Hadhrami yang dinamis dan berpengaruh. Dia juga seorang muslim pembaharu, juga pengusaha cerdas dan diplomat tangguh. Setibanya di Aceh tahun 1864, al-Zähir memulai karir bisnis dan politiknya berbekal pengalaman keagamaan dan perdagangan saat membantu mengembangkan hubungan bubungan diplomatik antara masyarakat lokal, Turki-Utsmani, dan kekuatan Eropa. Meski ia menyerah kepada Belanda pada tahun 1878, aktivitas dan pengaruhnya semakin menjadi bahasan utama dalam berbagai surat kabar kolonial hingga pertengahan abad 20. Artikel ini akan meninjau ulang peran politik al-Zähir dan ragam interaksi dengan para pesaingnya di kerajaan Aceh. Artikel ini menunjukkan persinggungan al-Zähir dengan pengadilan Aceh, uleebalang, dan Belanda yang secara sosial politik berperan dalam penyerahan dirinya kepada Belanda. Melalui pengamatan terhadap sumber-sumber Utsmani, Belanda, dan lokal, artikel ini menawarkan sekilas realitas terhadap tanggapan masyarakat lokal terhadap keputusan-keputusan Hadhrami yang paling terpercaya ini.

Kata kunci: 'Abd al-Raḥmān al-Zāhir, Aceh, Perang Belanda, Perang Sabil, Istanbul, Turki-Utsmani.

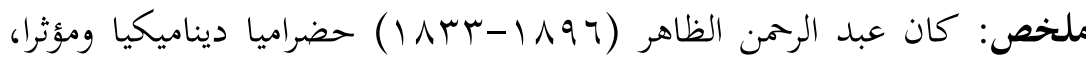

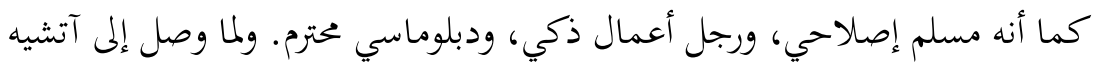

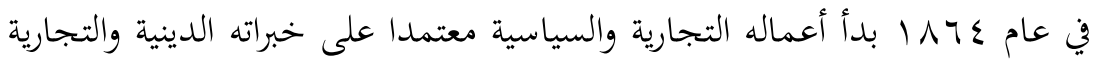
عندما كان يساعد في تطوير العلاقات الدبلوماسية بين السكان المانية المحليين والعثمانيين

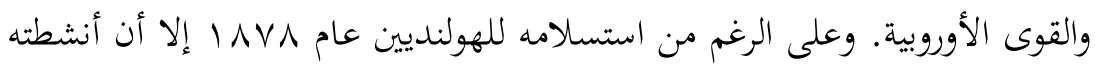

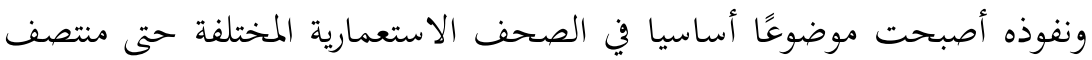

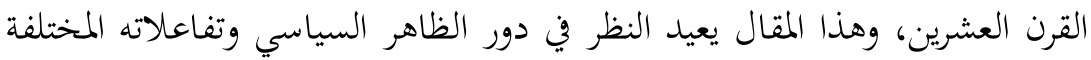

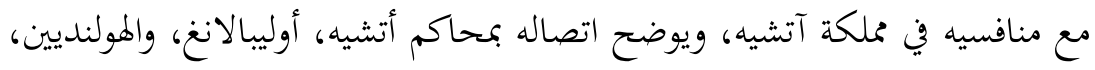

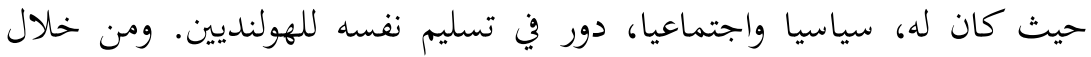

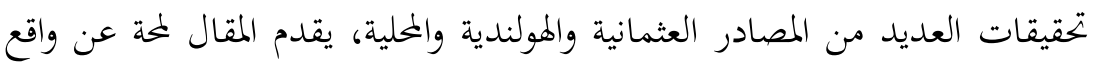
ردود السكان المحليين على قرارات هذا الحضرمي الأكثر ثقة. الكلمات المفتاحية: عبد الرحمن الظاهر، آتشيه، الحرب المولندية، الجهاد في سبيل الله، اسطنبول، العثمانيون. 
bd al-Rahmān al-Zāhir (1833-1896) was one of the leading
figures to aid the Acehnese during the war against the Dutch
in Aceh, known as the Perang Sabil. It is important to analyse al-Zāhir's political role and interactions within various circles, both in Aceh and abroad. By consulting his biographical data, I attempt to uncover crucial facts about al-Zāhir's life that contribute to our understanding of Acehnese development during this period.

In addition, I analyse al-Zāhir's stay in Aceh between 1864 and 1878 , along with his intermittently aligned relationships within various palace circles. I also look at his response to the expanding Dutch threat. Al-Zāhir's decisions have been much speculated about by numerous scholars who understand them as both complicated and controversial. I further discuss the ways in which the socio-political environment led him to act in contradictory ways.

Throughout this research, I advance the more general argument that biographical studies are illuminating not only with regard to considerations of the personal histories of respective individuals, but also with regard to larger segments of society and other related issues. As it has been rightly asserted, studying al-Zāhir's biography would help contribute to "a comprehensive understanding of the history" (Wilkerson 1990). In this regard, I believe that reconsiderations of alZähir's biography are crucial for properly re-evaluating this important epoch of Acehnese history of which he was an important part.

Some of the questions that will be considered in the forthcoming sections are: 1) What triggered his move from Singapore to Aceh in 1864 (1866)? 2) How did he gain support from various elite circles? 3) How did he impress foreign politicians, including those in Istanbul, the Islands of Penang and Singapore? 4) Why did he strategically exercise new negotiative manoeuvres during the war? These questions have not been adequately answered.

This paper argues for a reconsideration of the role of 'Abd alRaḥmān al-Zāhir through evaluation or reconstruction based on the available sources archived in the Dutch National Archive in Den Haag, Leiden University Library, the Ottoman Archives (BOA) in İstanbul, and libraries in Kuala Lumpur, Malaysia and Jakarta and Banda Aceh in Indonesia.

In particular, the nine-page text in Leiden is thought to have been written by Teuku Payah (Paja), who was a prominent trader living in 
Penang, a member of the Council of Eight (Dewan Delapan), and a major funder of al-Zāhir during his travel to İstanbul. This text is also assumed to have been translated into English by someone from Penang just before 1870 (Consulaat Penang 96, 9; Basiret, 25.04.1874, 1). ${ }^{1}$

This text sheds light on the initial stage of al-Zāhir's time in Banda Aceh and his relationships with various people, in particular the Sultan of Aceh and his court. Hence, the issue of his travel to İstanbul is not really explored in the text. And though the authenticity of this document might be questionable, it should not be dismissed outright as a useful historical record. No doubt, this corpus is different to some extent and does not include all developments in detail. Nonetheless, it is quite interesting to consider the body of information pertaining to al-Zāhir's initial stay in Aceh. In addition, I believe that the documents found at the Ottoman archive are significant and resonate with some of the other more general points made about him in his biography by other scholars.

Al-Zāhir is primarily remembered in his crucial role as the head of the envoy of Aceh court that travelled to İstanbul just before the war. He sought to revive the former political relationship between the Ottomans and the rulers of Aceh ("The situations of the Kingdom of Açin”, Al-Jawaib, 14 May 1873, 2; Woltring 1962, 624). He was also actively involved in war affairs once he returned to Aceh from Singapore and Penang. Al-Zāhir and his companions, including Teuku Nya Abbas, the nephew of Teuku Payah, covered their own expenses during their travel and stay in İstanbul ("The situations of the Kingdom of Acin”, Al-Jawaib, 14 May 18, 2). As Reid notes (1972, 39), Teuku Payah transferred money twice, totalling $\$ 6,000$, through colonial institutions to Contantinople. In fact, this view is supported by the abovementioned text of Teuku Payah.

Al-Zāhir became the political representative of the Aceh court and organized war preparations with the support and contributions from various groups, including some individuals of the Hadhrami diaspora residing in Penang. He interacted with various circles and engaged in the smuggling of war equipment during his involvement in the war. This behavior continued for at least the first four years of the war ("Jawa Items", The Straits Times, 16 December 1876, 2). As Reid (1972) writes, he took a leading position in compiling funding and contributing to the mobilization of tangible and intangible forces between 1868 and 1878 
until his voluntary surrender to the Dutch forces. He may have paid for these services for the Aceh court because of his personal attachment to Aceh. As Reid $(1972,37)$ writes, Aceh was a place where he felt at home.

Al-Zāhir might also be regarded as the promoter of the resistance movement againt the colonial Dutch forces (Lulofs 1954, 62). Hence, he also seems to have acted on the basis of his personal intention to acquire political and material wealth and may have changed his position later due to his own self interests (Reid 1972, 43). No doubt, he caused problems for the Dutch forces. He was described as a fanatical Arab within Dutch circles ("Java Items", The Straits Times, 27 May 1876, 1; "Netherlands India News", The Straits Times, 20 August 1885, 10) (Schütz 2010, 17).

\section{Some Insights of the Biography of 'Abd al-Raḥmān al-Ẓāhir (1833 (34)-1896)}

Habīb 'Abd al-Rạ̣mān al-Zāhir was born in 1833 in Tarim, Hadhramaut, in the southern part of the Arabian Peninsula. His father, al-Zāhir, moved to Malabar, on the southwest coast of India when he was a small child. He continued his early education in Egypt and the Hijaz, before returning to India where he received a degree under the tutelage of certain religious scholars (Reid 1972, 44-45). ${ }^{2}$

His full name was Habib Abdurrahman bin Syed Zahir, ${ }^{3}$ or in another saying, el-Said Abd-ul-Rachman el-Zahir. Affectionately, he was called Sjajid Abdoerrachman or Habib Abdoerrachman (Lulofs $1954,43)$. On the other hand, one of the documents notes that his name is read as 'Abdurahman ibn Muhammed ez-Zahir Ba-Alwi'. ${ }^{4}$ It is safe to say that, on the basis of the latter document, al-Zāhir belongs to the Ba Alawi family, which was recognized as an influential Hadrami family throughout the archipelago. ${ }^{5}$

Al-Zāhir's name emerged in Ottoman archival documents pertaining to his official visit to the governor of the Ottoman State in Mecca. ${ }^{6}$ According to these documents, his full name is as-Sayyid 'Abd al-Rahmān al-Zāhir and he was the deputy of the Sultan of Aceh, the primary representative of the Sultan, and referred to as al-Mutasarrif al-Mutlaq, Maharaja Mudabbir al-Malik al-Sayyid 'Abd al-Rahmōnn alZähir. ${ }^{7}$ His name is also read as Raja Mudabbir al-Malik al-Sayyid 'Abd al-Raḥmān ibn Muhammad Al-Zähir or as seen in the stamp with his 
title "ad-dai Wazir Hakim Açi". ${ }^{8}$ The latest document refers to him as Seyyid Abdurrahman ez-Zahiri or ez-Zahidi. ${ }^{9}$

His father's name, as understood from the stamps in some official letters, was Muhammad al-Zāhir, read as Maharaja Mudabbir al-Malik al-Sayyid 'Abd al-Rahmōn ibn Muhammad Al-Zähir in the single stamp dated $1287 .{ }^{10}$ In some other documents, al-Zāhir is referred to by the title of 'Pasha' (Seyyid Abdurrahman Zahir Paşa). This is the first time I came across him being referred to as an Ottoman 'Pasha'. ${ }^{11}$ It also seems that some of the latest documents discussing Aceh-Ottoman relations summarily refer to him, but with a different political affiliation such as 'interior minister of the Aceh government', and as the wazir and surrogate (wakil-i mutlak) Aceh Sultan, ${ }^{12}$ which differs from the early references defining him as seen above. ${ }^{13}$

Al-Zāhir was not only personally presenting himself to the Ottoman governor in Hijaz, but he also submitted official letters with his own signature and stamp on behalf of the Sultan of Aceh. ${ }^{14}$ In a letter, which is understood to have been dictated by the Sultan himself, he presents Abdurrahman as the Maharaja, a title which was often used in Malay ruling quarters, and which is similar to the position of prime ministership in contemporary political discourse. In the same text, alZāhir was also referred to as 'advisor to the Sultan of Aceh' or 'mudabbir al-malik'. ${ }^{15}$ In another text in the same file, he was referred to as wazir and only as a single representative of the Sultan of Aceh, by referring him as 'wakil-i mutlak'. 'Abd al-Raḥmān al-Zāhir was not alone in his task as an envoy to the Holy Land under the protection of the Ottoman state; he was accompanied by a group of political elites, who referred to him as "umera ve ayan" from Aceh. ${ }^{16}$

Though al-Zāhir's visit got more attention in the İstanbul press (Reid 1972, 41; Basiret 05.06.1873, 1; Basiret 07.06.1873, 1; Basiret, $11.06 .1873,1)$, his name is not quoted in any books on İstanbul history or travellers' books. For instance, a book entitled "Seyyahların Aynasında Şehirlerin Sultanı İstanbul" mentions various envoys and visitors in 19th century, but the name 'Abd al-Raḥmān al-Zāhir is left out, unlike other Eastern visitors (Meriç et al. 2010).

It appears that al-Zāhir himself preferred the title ' $h a b i ̄ b$ ', as witnessed in a letter he wrote in which he referred to himself as Habib 'Abd al-Raḥmān al-Zāhir and to others as, for example, Habib Osman or Habib Abubakar. He also refers to some other individuals as ' $h a b i b s$ ' 
in this relevant paper. ${ }^{17} \mathrm{He}$ followed almost the same life trajectory, being a trader and approaching traditional courts as an advisor, like the majority of Hadhramaut people who were scattered throughout the adjacent regions of the Indian Ocean.

After he completed his religious-based education, al-Zāhir sought to become involved in commercial life. He was an active merchant in various port cities, in particular in Penang and the Singapore Islands in the Malay Peninsula and Pidie (Pedir), which was historically renowned for being one of the best pepper production centers in northern Aceh. His being in the port cities of the Straits of Malacca led al-Zāhir to reach Singapore and become closer to Abubakar, then newly inaugurated Sultan of Johor in 1862. After serving almost one-and-half years as a senior administrative staffer, he left for Sumatra (Reid 1972, 45-46; Historical Notes of Singapore, 8).

Al-Zāhir first arrived in Aceh in 1864, accompanied by Syed Omar from Singapore, through Pedir, on a vessel called Comnay. He had come to the province principally for commercial purposes. With regard to his being in the region, it is thought that he moved from Kalikut, Madras (Malabar), to the port cities of the Malacca Straits around 1863 (Consulaat Penang 96, 1). ${ }^{18} \mathrm{He}$ assumedly spent time exploring business opportunities in Penang and Singapore. This is relevant insofar as it demonstrates that he was not only involved in politics, but also commercial activities. Al-Zāhir was also active on behalf of the Sultan of Aceh in commercial activities between North Aceh (Ide region) and Penang. This can be regarded as further evidence that he was active beyond his official responsibilities to the Aceh government; he was also actively involved in business affairs. ${ }^{19}$

In this regard, it can be safely argued that he was following the same prototype of the Hadhrami commercial activities (Mandal 2013, 242). During this time, port administration was dominated by the South Indian Muslim merchants with whom al-Zāhir had a close affinity.

$\mathrm{He}$ did not find any commercial opportunities in Pedir and so returned to Langkawi. After a brief period, he returned to Aceh and this time landed in Banda Aceh, most likely just prior to his 31st birthday. He settled in Kampung Java, which was a recognized metropolitan district that fell under the rule of the Sultan of Aceh, and in which there might also have been some Arab communities (Consulaat Penang $96,1)$. 
This village is renowned for its shrine to Said Abubakar al-Bafaqih, an 18th century scholar who was better known as Teungku di Anjong, from Hadhramaut. A mosque that once functioned as a religious study center was founded next to his tomb (Hill 1955, 57; Hurgronje 1906, 156). In recent years, this place has been widely remembered as an Arab village. For instance, during my interviews with some of the elderly people of the region, one respondent observed that Kampung Java was considered an Arab village owing to the majority of its settlers being of Arab descent. ${ }^{20}$

While Al-Zāhir gained recognition and popularity among the general public, he was particularly well-known among the political elite, such as the uleebalang and the Acehnese court. This was undoubtedly because of the respect and reverence of the Acehnese people to the habibs (Hurgronje 1906, 155). On the other hand, al-Zāhir's knowledge and skills in political and religious affairs should not be exaggerated. Though he was qualified in these fields, I believe that political decision making processes were held by the Acehnese themselves as a last resort. This was proved during the initial years of the Dutch War. After alZāhir left, his role and function was replaced by the Acehnese religious scholars themselves.

Furthermore, when the Acehnese court discussed the demands of the Dutch colonial rulers, specifically their desire to gain possessions of several islands, including Pulau Weh and Pulau Nasi (Weh and Nasi Islands), the Acehnese court rejected those demands, before charging the wazir or perdana menteri (prime minister) with the responsibility of announcing Aceh's decision to declare its autonomy (Mutyara 1947, 19).

This fact is also observed in a text written by al-Zāhir himself in which he refers to the Advisory Council (Majlis Penasihat). ${ }^{21}$ His appointment as the head envoy to İstanbul was based on a decision made by the Acehnese court, as I note later. When considering the various sources on Al-Zāhir, it is clear that there are some controversial issues pertaining to the relationship between al-Zāhir and Sultan Mansur Syah. I further explore this relationship in the forthcoming sections.

\section{His Family Based on the Ottoman and Other Sources}

Before discussing al-Zāhir's role and place in Aceh during the turbulent 19th century - turbulent because of the Dutch invasion of Aceh - I offer some information about his family. 
Al-Zāhir had six wives, some Turkish Circassians, and Habshi concubines. He married the daughters of other Sayyid families in the region, with one exception being his marriage to an Acehnese woman called Potjut, who, according to Snouck Hurgronje, might have been the widow of former Sultan Mansur Syah. His multiple marriages happened during his travels through Mocha, Penang, Singapore and Aceh. During his time in Penang and Kedah there was a Turkish Circassian, along with some servants and slaves among his retinue (Bake 1873, 69; Hurgronje 1906, 23; Reid 1972, 38). It is also understood from Ottoman documents that al-Zāhir had a son named 'Seyyid Ahmed Bey' and a daughter named 'Seyyide Ayşe Hanım' . ${ }^{22}$

The correspondence of the Dutch consul in Jeddah also indicate that al-Zāhir was married to the widow of the former Sultan, Raja Sulaiman (Bake 1873, 69). Reid writes that Teuku Muda Ba'et, one of the influential uleebalang of Mukim VII, married his then child daughter with Raja Sulaiman in the 1850s. Al-Zāhir acted against the rule of Teuku Muda Ba'et to get Tuanku Mahmud from his hand on the basis of the policy of Sultan Mansur Syah. He married Potjut in order to acquire an upper hand in Acehnese politics (Reid 1972, 49). By virtue of this marriage, al-Zāhir became the rightful protector of Tuanku Mahmud, the newly appointed Sultan Mahmud, and he was able to establish an alliance with Teuku Muda Ba'et, a former foe (Bake 1873, 67).

Reid writes that Potjut (Reid 1972, 38), ${ }^{23}$ the Acehnese wife of alZāhir, was an exception, while the rest were members of Sayyid families. Al-Zāhir was, however, also married to several other women in Aceh. It is believed that al-Zāhir was married shortly after his arrival to Aceh Besar in 1864. He first lived in Kampung Jawa, before moving to other villages in Aceh Besar, including Kampong Lamboeh and Kampung Lamsimpang. It appears that he offered to marry a daughter of an Arab family in the latter village when he was 31 or 32 years of age (Consulaat Penang 96, 1)..$^{24}$

There exists another reference to his marriage with another Acehnese lady, the sister of Tuanku Loeng Batta, who is remembered as a fierce fighter and leader of the Acehnese army. Though Reid mentions that none of al-Zāhir's wives accompanied him during his travels (Reid 1972, 38), there is a reference contained in the Teuku Paya text that 
he was preparing to perform the hajj with one of his Acehnese wives (Consulaat Penang 96, 8). Interestingly, his wives did not accompany him on long travels, which is the main reason it appears that he had multiple marriages. Al-Zāhir had a few "servants or slaves", including "a Turkish Circassian" with whom he consorted during his time in Kedah and Penang (Reid 1972, 38; Schmidt 1992, 61). Hurgronje (1906, 23) also mentions that he brought several concubines from India during his travel to Aceh.

One of his wives (as Schmidt notes "the second wife") was in Mecca during his visit to İstanbul in 1873 . On the other hand, Schmidt again states that al-Zāhir left İstanbul to visit his second wife in Mecca. Some Dutch officials speculated that al-Zāhir had stated that he had been forced to pay a visit to Porte. Schmidt also refers to Potjut while referring to Reid's work. Schmidt's paper also indicates that al-Zāhir had a 3-year old daughter in Aceh $(1992,61)$. Another of his wives was named Syarifa Fatimah, which suggests that she was a daughter of a Sayyid family (Reid 1972, 45). Potjut, the sister of Teuku Muda Ba'et, was previously married to Sultan Sulaiman Iskandar (1838-1857). AlZāhir argues that his father-in-law and some other family members were killed during the initial stages of the war in Aceh (Reid 1972, 49; Schmidt 1992, 61).

Ottoman documents reveal that the name of one of al-Zāhir's children was 'Seyyide Ayşe Hanım', which indicates that she came from a Sayyid family. Hence, it is assumed that she was named like an Ottoman lady, as seen in the spelling of her name 'Ayşe Hanım' or 'Şerife Ayşe Hanım. ${ }^{25}$ The reason she is mentioned in the document is related to her being taken to prison by the Dutch authorities in Batavia. Based on the details of the same document, it appears that Ayşe Hanım returned to Kota Raja, Aceh, from Jeddah after al-Zāhir passed away. The same account also suggests that Ayşe Hanım's mother was in Aceh and that she wanted to be the protector of Teuku Ali, her uncle from her mother's side in Aceh. ${ }^{26}$

This is an important thing to consider because it sheds more light on the life of al-Zāhir and his political relations in Aceh. It is said that Ayşe Hanım was imprisoned in Batavia. Though Ayşe Hanım was able to travel from Jeddah to Kota Radja, the capital city of Aceh, she was interrogated and imprisoned by Dutch authorities in $1897 .{ }^{27}$ 


\section{The Political Situation in Aceh}

The political situation in Aceh prior to al-Zāhir's arrival warrants a brief discussion. These were tumultuous years when it was clear that the Dutch were determined to invade Aceh in order to expand their colonial influence. The Dutch colonial administration in Batavia engaged in activities that appeared to be in preparation for a military invasion, in particular near the southern border of Aceh with Padang. The Dutch also had imperial ambitions with regard to less geostrategically important states in Eastern Sumatra (Chaniago 2002, 27). ${ }^{28}$ Beyond this external threat, the Acehnese appeared to have been divided between the Aceh court and the periphery, as well as the uleebalang of Sagis, who, historically, were powerful and wealthy political elites.

Once al-Zāhir reached Aceh, the common folk and particularly the more educated people known as religious scholars, hajis, and Lebbai (religious scribers), were attracted to him due to his perceived knowledge and charisma. The common folk saw him as somone who could protect them. Thus, his reputation increased among the Acehnese, who visited him when they needed his assistance. No doubt, his presence in Banda Aceh caused both envy and concern among many different circles (Consulaat Penang 96, 2).

In particular, his approach to the state and condition of mosques gained him favor with the Acehnese. His first initiation was to attempt to renovate the collapsing Masjid Raya Baiturrahman. Through this, he emphasized the importance of having a vigorous religious life and argued that, as good Muslims, the Acehnese community was obliged to take care of religious buildings such as the historical mosque of Baiturrahman. This symbolic act demonstrates that he had a scholarly approach to the socio-political conditions in the capital city of the Sultanate of Aceh. Al-Zāhir most probably felt superior to the locals and ordered the Acehnese to renovate their mosque. No doubt, this is why he was so distraught about the condition of the Baiturrahman mosque, even though the Acehnese were regarded as devout Muslims (Consulaat Penang 96, 1-2).

It was during this crucial period that al-Zāhir proved himself to be an authority on religious matters. His initiation of fundraising for the mosque renovation was appreciated by Sultan Mansur Syah, and after a while, his growing notoriety led to him being introduced to the Sultan in person. The Sultan acknowledged al-Zāhir's enigmatic 
persona and, by getting closer to the Sultan, Al-Zāhir contributed Aceh politics under the patronage of the the former who had to continuously navigate the turbulent relations with the uleebalang (Bake 1873, 68). Here, a letter which was given by Sultan Abubakar of Johor to al-Zāhir pertaining to the latter's service during the early years of 1860s in Johor, must have been effective for Sultan Mansur Syah to receive al-Zāhir in a positive manner. Despite the above-mentioned closer relationship, it is understood that the Sultan, after a while, sought to punish al-Zāhir owing to the latter's extension of authority among Acehnese society (Consulaat Penang 96, 2-4). ${ }^{29}$

Because of the involvement of some rajas, al-Z̄ahir left for Arabia and, almost a year later, returned to Aceh. Seeing that the Sultan was ill, he apologized to the Sultan for his previous attitude. As accounted in the text, the Sultan Mansur Syah forgave him and appointed him as the head of one of the mukims (Mukim III) (Consulaat Penang 96, 6). Mukim III (Tjot Putu) would play a crucial role during the inaguration of Tuanku Mahmud, the son of Raja Sulaiman, as the heir of the palace on the decision of Sultan Mansur Syah. During this politically critical period, al-Zāhir was appointed to deal with this issue. He also mobilized the settlers in Mukim III, in addition to the palace military unit that he also mobilized (Reid 1972, 47).

It is important to note that even before his publically voiced concerns about the mosque, al-Zāhir was already recognized by at least some of the distinguished and influential Acehnese political elite. Al-Zāhir, like his clan members, adapted well to Aceh. He was particularly successful navigating palace circles and political elites. He eventually acquired one of the highest-ranking positions as an advisor to Sultan Mansur Syah and head of envoy to İstanbul to restructure relations between the two political entities, both of which were Muslim powers in previous periods, including the 16th and 17th centuries, as well as the mid-19th century (1850/51) ("Items from the Java Papers", The Straits Times, 19 June 1875, 2; 7 Numaralı Mühimme Defteri (I), No: 233-244, 118126; Kepper 1874, 36-37; Vink 1985, 2). ${ }^{30}$

Some other sources have indicated that al-Zāhir was appointed as kadi and chief imam of the mosque of Baiturrahman on the basis of his relationship with the court (Vink 1985, 2). Many believed al-Zāhir had impressive religious credentials. Indeed, he was considered by regional journals in the 1870 s as a religious authority, partially due to his 
influence among the Acehnese political elite. ("Java Items", The Straits Times, 24 June 1876, 1; “Java Items”, The Straits Times, 27 May 1876, 1 ; Roff 1985, 20). This appointment was not, however, for the position of Shaykh al-Isläm, but an imämship and as director of religious affairs (Reid 1972, 46).

Because of this, al-Zāhir appears to have developed a close affinity with the nobility, which provided him their support. This is also evident in documents that discuss his travel to Mecca to foster political collaboration between the Ottoman State and the Sultanate of Aceh Darussalam. Al-Zāhir also appears to have been accompanied by a small delegation of Acehnese nobility representatives. ${ }^{31}$ He acquired strong support from some 20 different religious groups and nobilities, all of which signed a petition to be submitted to the Ottoman governor in Hijaz.

This tradition is not only limited to the palace circle - it also applied in both noble and public circles. For instance, the official letters submitted by the Acehnese envoys to the Ottoman bureucracy, in particular to the Hijaz, proved that the nobililites not only played a significant role in domestic politics, they also enjoyed influence over international relations. There were a total of 20 individuals aside from al-Zāhir that came to Mecca. ${ }^{32}$ Being the head of the envoy, al-Zāhir approached the Ottoman Wazir along with other officials to talk about getting military and political support from the Ottomans through the governor of Mecca.

After Sultan Mansur Syah passed away in 1870, al-Zāhir appeared as close aide to the Sultan's wife and took a leading role in the inauguration of her 16 year-old son from the late Raja Sulaiman (Consulaat Penang $96,7)$ (Vink 1985, 2). The same process is observed in the account of Szekely. Al-Zāhir, arguably, was appointed to a more significant position when he was appointed as Wali of the younger Sultan Mahmud Syah (Lulofs 1954, 45). This account, however, is somewhat dubious given that al-Zāhir was married to the wife of Mansur Syah or Raja Sulaiman.

\section{Al-Z̄āhir: A Controversial Figure?}

Al-Zāhir's visit to İstanbul needs to be analysed in terms of his promoting a Pan-Islamist ideology within a larger geographical context; one that pre-dates Abdulhamid II, (Landau 1992, 10-11; Lee 1942 , 249), who is generally regarded as the primary supporter of a 
political union between Islamic lands that were under colonial rule. In this regard, as is often mentioned in the relevant literature, Aceh was referred to as "the bulwark of Islam in the Indies" (Simon 1912, 224). From the standpoint of the Acehnese, they were "defending their religion and their fatherland" during the war in Aceh (Chauvel 1990, 40-41).

My position, however, is that al-Zāhir's policies were controversial. Acehnese writers typically emphasize the initial stage of the war, particularly the fights around the Baiturrahman mosque, the killing of J. H. R. Köhler, the commander of the Dutch forces, and the third stage, which was led by ulama forces and the Tiro family. In publications, including Sinar Darussalam, Acehnese scholars and researchers do not mention al-Zāhir's name as often as other heroes, such as Tiro family members Teuku Omar, Cut Nyak Dhien, and others. ${ }^{33}$

From personal conversations and talks with academics and religious scholars, I noticed how little emphasis has been placed on the role of al-Zāhir reforming the Islamic practices of the Acehnese. Furthermore, little has been written about al-Zāhir's thoughts and actions after his surrender or during the later period of the Dutch War. This is relevant because al-Zāhir was recognised both as a Sayyid and as a person who advanced his study of Islamic law; indeed, this is why he first acquired fame and recognition as a prominent religious scholar ("Java Items", The Straits Times, 27 May 1876, 1).

Al-Zāhir was well received by the Acehnese when he was actively involved in political affairs during his time in Aceh. He did not, however, write any scholarly works, treaties or risalah, even though he was appointed as the principal imam to Baiturrahman Mosque and was regularly approached for advice on religious matters (Reid 1972, 48, 51). Hence, al-Zāhir found himself in somewhat desperate situations, either by his own doing or due to external factors, which led the Acehnese to gradually lose trust in him. This is evident in the archipelagic media from the time. As witnessed, the Acehnese already lost their trust in him because of his failed attempt in İstanbul ("HindiaNederland: Negri Atjeh”, 1). One would assume that this accounts for why the Achenese have kept relatively silent about his contributions. The Acehnese attitude towards al-Zāhir might also have been related to his controversial approaches and practices, such as taking sides with some elites while opposing others. 
It is also true that he got frustrated after his unsuccessful efforts in İstanbul. His popularity declined after his surrender to the Dutch, and he retired to Hijaz in 1878. Al-Zāhir's decision to surrender to the Dutch seems to have been made during an early stage of his involvement in Acehnese politics just before the Dutch War. One source argues that he sought a peace agreement with the Dutch in order to derive some benefit from them during the war ("Jawa Items", The Straits Times, 24 June 1876, 1).

Al-Zāhir was involved in many different circles of politics throughout his time in Aceh, starting with his landing in Kampung Jawa where he successfully won the hearts of the common folk and established alliances with elite circles later on. He was widely acknowledged as being knowledgable on political and religious matters, and was talented in debates.

That aside, as Reid notes, al-Zāhir never achieved national hero (pablawan) status in the history of modern Indonesia (1972, 37). Pahlawanship has been attributed much significance since Indonesian independence. According to an article published in a military journal two years after independence, "Every independent country must have heroes and these heroes have a role and function of spiritual strength and dignity of the State" (Loethfy 1947, 15). In addition, some Acehnese that were considered to have played significant roles during the Dutch War were inaugurated as pablawan by the national government in the relatively early decades of Indonesia. ${ }^{34}$

Reid acknowledges certain issues that explain why al-Zāhir was not made a pablawan. That said, Reid does not appear to have acknowleded these issues intentionally when he traces al-Zāhir's movements during the war in Aceh. For instance, Reid writes, '... Al-Zāhir acknowledged no loyalty to any particular country or people'; '... He never had any illusions that Atjeh could win a war with the Dutch'; '... When he finally returned to Penang three months later, he was clearly at the end of his tether. Reluctant as he was to return to fight a losing war'; 'He knew in the end the Achinese would be beaten..." (Reid 1972, 37, 38, 42).

When he failed to convince the Dutch of the need for a peaceful end to the war, he returned to Aceh to continue the struggle for a second time, "though being reluctant". In fact, it seems that he was not particularly enthused about this whatsoever. Another narrative notes 
that when al-Zāhir returned to Singapore and Aceh, he approached the Dutch officials about a peace agreement, while at the same time making efforts to mobilize the Acehnese against Dutch forces (Schmidt 1992, 62).

On the other hand, despite this renowned Islamist's reluctancy to continue the struggle, the Acehnese themselves maintained their resistance, which the Dutch authorities in Batavia and Den Haag recognised and argued that the Acehnese did not have any desire to end the war ("The Acheen War", The Straits Times, 1885, 7). Similar accounts from the relevant years from the Dutch side exist as well: “... How vacillation which has characterized Dutch operations in Aceh affects the Dutch soldier. Desertion ... has become common, and defeat disgracefully usual." ("The Acheen War", The Straits Times, 1885, 10). Or "... Fanatical Acehnese who have successfully warred against us for 12 years, and whose courage, patriotism, and self sacrifice are worthy of a better cause are capable of anything" ("Netherlands Indian News", The Straits Times, 1885, April 11, 4).

Needless to say, al-Zāhir contributed much towards the resistance movement against the Dutch ("Java Items", The Straits Times, 30 December 1876, 2; "Acheen Affairs", Straits Observer, 20 June 1876, 3). He was recognized for his cosmopolitan background, having studied in Egypt, Mecca and Western India. He had commercial ventures in port cities adjacent to the Malacca Straits, and had interacted with the Hadhrami diaspora, as well as Westerners and colonial rulers. In addition, as Reid $(1972,45)$ notes, al-Z̄āhir was a global figure during his time as a chief envoy between the Sultanate of Aceh and İstanbul. He regularly visited Europe during this time. At the same time, however, he was regarded as an outsider. The Acehnese did not adopt him as one of their own (Consulaat Penang 96, 4). He was considered impolite and aggressive in contrast to the "the traditional politeness" (Reid 1972, 41) of the Acehnese common folk and nobility. This was a major reason why he was never really accepted.

\section{Al-Z̄āhir as a Voice of the Acehnese Resistance}

Al-Zāhir was recognized as one of the leading figures of the prewar era in Aceh. He was a distinguished figure not only in Aceh, but also in Malaya, particularly on the island of Penang. This point was noted in many different Dutch sources prior to the Dutch War, before 
and during the rule of the colonial governor of Karel van der Heyden (Paulus 1917, 5). It is argued that he gained recognition as head of a political envoy to İstanbul, twice sent at the behest of the Acehnese court. His second visit was facilitated by Acehnese political elites represinting the newly appointed young Mahmud Syah. During his time as leader of the envoy, he allegedly became the leader of the war in the second phase, which started toward the end of 1873 after his return from İstanbul ("The Situations of the Kingdom of Açin", Al-Jawaib, 14 May 1873, 2) (Lulofs 1954, 61).

Al-Zāhir played a crucial role in mobilizing the wealthy Acehnese in Penang, including some members of the Arabian community, to support the war in Aceh. He did this through various means, including establishing and implementing policies, supplying armament, and mobilizing the nobilities in distinct regions of Aceh. He did this over four years via his network of Penangise and Acehnese nobility. Owing to his strong character and commitment to the cause, Szekely brought al-Zāhir into the politico-religious fold of leading people, including Teuku Omar, Teungku di Tiro, Teuku Neh Merassa and Tengku Loeng Bata (Bake 1873, 69; Moeis and Lulofs 1954, 5; "Jawa Items", The Straits Times, 27 May 1876", 1; “Jawa Items”, The Straits Times, 3 June $1876,1)$. As contained in a short letter believed to have been written after his return from İstanbul, al-Zāhir also organized local leaders, including some Habibs in Aceh, encouraging them to take part in the war. $^{35}$

Once Mansur Syah (1857-1870) and his successor Mahmud Syah (1870-1874) failed in their attempts to establish political relations with some of the leading Western powers, most specifically, with the British, the Acehnese political elite decided to send a diplomatic envoy led by 'Abd al-Raḥmān al-Zāhir, who was regarded as Wazir of Aceh (Schmidt 1992, 58; Veer 1977, 130). ${ }^{36}$

While the Acehnese envoy was engaging in diplomacy in İstanbul, the Dutch Kingdom had intervened through its consul via a man named Henri Antoine Heldewier (1872-78) in the Ottoman capital, who benefited from his close ties with the Russian consul, George Ignatief (1864-1877). Other European allies of the Dutch, including the French, Germans, Austrians, Italians and, in particular, the British, also intervened to prevent any affirmative response from the Ottoman government by siding with the Acehnese through a declaration of support to the Acehnese 
envoy. The Western powers regularly meddled and threatened Saffet Pasha and subsequently Reşid Pasha, both of whom were foreign affairs ministers of the Ottoman government. Midhat Pasha and Hidiv Pasha were also among the individuals from the Ottoman goverment who met al-Zāhir (Schmidt 1992, 58-59; Veer 1977, 130; Basiret, 07.06.1873; Basiret, 11.06.1873; Basiret, 13.06.1873).

The European nations did this through their various consuls in İstanbul to obstruct the Ottomans' active involvement in the Dutch War in Aceh because of their fear of further Islamic expansion and consolidation of power. The Ottomans represented a distinct challenge to the colonial powers in certain regions (Schmidt 1992, 66). It is not possible to determine whether the issue of Ottoman expansion to include Aceh became a point of discussion, as it did in previous years among various members of the British government (Straits Government Gazette, Friday 17 April 1863, 164-76). The same issue was considered by the Ottoman press during the Acehnese envoy in 1873, which referred to an Acehnese vassal stateship under Ottoman protection and sovereignty (Basiret, 07.06.1873, 1).

\section{Al-Z̄āhir and the Support of the Uleebalang}

The reason al-Zāhir received the support of the nobles in Aceh, as can be ascertained from letters with stamps and the names of relevant nobles submitted to the Ottoman court, was largely due to ongoing political disputes in Aceh. In particular, during the earlier part of the 19th century, the Aceh court fell under the strong influence of the leaders of the Sagis, or autonomous regimes in three corners surrounding the capital city who held control of regional trade (Tarling 1957, 123). The Dutch were close observers of Aceh and Acehnese politics, and discovered that there were two factions fighting to get a foothold in central government (Bake 1873, 69).

Based on the availability of current data, I believe it necessary to briefly discuss al-Zāhir's political expedition before he arrived in İstanbul in 1872. Al-Zāhir is assumed to have left Aceh towards the end of 1872 in order to submit a letter from the Sultan of Aceh to the Ottoman government (Al-Jawaib, 14 May 1873, 2) (Brugmans 1930, 309; Hasjmy 1978, 475).

Dutch sources, through their consul in Jeddah, noted that al-Zāhir landed in Jeddah in the middle of January 1873. He spent almost two 
months in Jeddah, during which time he met with the consul on several occasions (Bake 1873, 55, 66).

After this phase in his travel, he most probably arrived in İstanbul at the beginning of April. According to Schmidt, al-Zāhir arrived in İstanbul on 27 April 1873 on an Egyptian ship, and he stayed for a few days at the Özbekler Tekkesi in Üsküdar (Schmidt 1992, 59; Veer 1977, 127). According to another account, the Sultan of Aceh sent a letter with an envoy to İstanbul in October 1872 (Reid 1969, 81). Alternatively, he was supposed to continue his travel to some European capitals. But it seems it did not happen (Bake 1873, 70).

Although there were rumours of al-Z̄ahir attempting to visit İstanbul on behalf of the Acehnese, al-Zāhir was recognized as the last political agent of the Acehnese to visit İstanbul (Schmidt 1992, 62). Al-Zāhir was confident that his first visit to the Ottoman court would be positive. During meetings with various circles, he proudly delivered a speech on Aceh's relations with Turkey, England and France (Alof 1873, 66; Kepper 1874, 17; Al-Jawaib, 7 May 1873, 7).

Since he was a prominent politician within Aceh palace circles, it is likely that he was given permission by the Acehnese Sultan to represent and discuss all relevant issues on behalf of him and his authority. It appears that he was confident that he would be successful during his first visit (Alof 1873, 66).

Al-Zāhir's confidence was primarily based on his meetings with Nuri Pasha, the Ottoman governor in Hijaz. It is widely assumed that al-Zāhir must have had talks with the Pasha during his time in İstanbul. As contained in the accounts of the Dutch consul in Jeddah, "the Pasha repeatedly indicated that Atchin belong to Turkey and that a Turkish genderal had transferred a Turkish flag to the ruler of that state" (Bake 1873, 28). It is important to note that al-Zāhir brought with him letters containing a significant number of historical references establishing previous Acehnese attempts to revive a political alliance with the Ottoman capital. ${ }^{37}$

\section{Al-Z̄āhir as a Prominent Leader}

Al-Zāhir's active participation in the Dutch war made him a prominent figure among his Hadhrami clan, notwithstanding that he was never confident that the Acehnese would be victorious. Al-Zāhir used his political skill to garner support not only from the palace 
circle, but from other prominent nobles, who traditionally dominated the political decision-making process. In fact, al-Zāhir was widely acknowledged as the most influential leader among the Arab contingent in the Acehnese palace (Bake 1873, 69).

There is consensus that al-Zāhir's political approach was 'ambitious and skillful' (Hurgronje 1906, 147). Beyond his education at various elite educational institutions in Egypt, Mecca and India, he appears to have also acquired some political and administrative skills through his being employed as the head of a mid-sized army unit in India. It is also believed that he was indirectly involved in political life during his time living under British rule in Penang and Singapore. All these experiences made him skillful enough to become an important figure in Acehnese politics (Reid 1972, 45-46).

Al-Zāhir was appointed as wazir, or prime minister, in the Acehnese government, and led the Acehnese envoy to Hijaz and İstanbul just a short time before the Dutch War. Furthermore, he was able to organize a 'liberation front' to collect funds, military equipment, and human resources (i.e. mercenaries) to support Aceh's struggle through his effective network in Malaya. His personal initiative to have a course of interactions with the British authorities in Penang and Singapore gave him a distinct role in the war in Aceh. According to records, alZāhir was involved with various consuls of countries, including Siam, in order to establish a political alliance on behalf of the Aceh court. In this regard, he visited Chow Phya Baduwongse, the Siam council in Singapore ("Java Items", The Straits Times, 30 December 1876, 2; "Items From the Java Papers", The Straits Times, 19 June 1875, 2; Basiret, 18 Mayıs 1873, 1).

Aside from his affinity with certain palace circles, al-Zāhir also attempted to mediate between the Dutch and the Sultanate of Aceh in the hopes of reaching a peace agreement just before the Dutch declared war (Reid 1972, 51). He was frustrated upon his return because of the loss in trust of the Council of Eight after he attempted to engage with Dutch authorities to establish peace talks through the Sultan of Johor. In the end, the Dutch did not sympathize with him, effectively compelling Al-Zāhir to continue the war in Aceh.

This was, in large part, a result of the Ottoman government not being able to provide the Acehnese with military support, notwithstanding that it offered the Dutch government a peaceful resolution. The talks 
between al-Zāhir and the Ottoman leaders may have caused the former to act this way after they saw the Acehnese make no significant progress inroads against the Dutch. The distinctiveness of Acehnese diplomacy also seems to have fallen on deaf ears in İstanbul. Nevertheless, while the Acehnese envoys visiting on the eve and initial stage of the Dutch War presented well in vernacular widely used by the media in İstanbul, the same thing cannot be argued for the decision-making process. It was not handled well by the main political actors in the Ottoman government.

\section{Al-Zāhir as an individual Hadhrami}

Al-Zāhir was not a member of any particular group of Hadhrami immigrants who spent their lives in Aceh. It is therefore difficult to conclude that he developed a Hadhrami institutional base to help him move into Acehnese political and social life. He made his own political inroads primarily because of his own capabilities and the knowledge he acquired throughout his earlier life. His time in Islamic study centers in Egypt, Arabia and India proved beneficial to him. Beyond this, his political acumen was surely related to his business skills and 'sayyid network' in the region. This was especially the case in the various port cities in the adjacent regions of the Indian Ocean.

Al-Zāhir was not interested in improving the scholarly tradition in Aceh by involving education centers. Instead, he tried to establish a political niche for himself and used his religious credentials to bolster his claims for power and political recognition. Throughout the war, both while in İstanbul accepting a nişan ${ }^{38}$ and later on while trying to be a peacebroker for the Acehnese political elite and the Dutch colonial representatives in Singapore, al-Z̄ăhir arguably sought political glory above all else. Reid emphasizes that al-Zāhir sought to surrender to Dutch colonial rule in exchange for material benefits and other perks. He lived out his final days in Jeddah with money that the Dutch provided him as a living stipend until his death (Hassan 2004, 405). ${ }^{39}$

During his time in Jeddah, al-Zāhir approached Osman Nuri Pasha, the governor of Hijaz, in order to get the recognition of the Ottoman government that he had always sought. He received a second class Order of the Medjidie for his efforts. He spent the rest of his life bouncing between Mecca and Jeddah. ${ }^{40}$ Al-Zāhir ultimately accepted defeat in the war, surrendering to the Dutch in exchange for a monthly 
salary of $\$ 1000$ to stay in exile in Hijaz beginning on 13 October 1878 . This was more than enough to afford him a comfortable life in his final days (Paulus 1917, 79; Schmidt 1992, 62). ${ }^{41}$ During his stay in Hijaz, particularly in Jeddah, it is unclear whether or not he maintained his close relationship with the Ottoman governor or if he ever sought more assistance for the Acehnese in their ongoing struggle against the Dutch.

\section{Conclusion}

The reasons behind al-Zāhir's extensive involvement in Acehnese politics needs to be further analysed. Hassan argues that "... the main concern of 19th century Arab migrants was in accessing opportunities to get employed in relevant state's administrative bureaucracy, undertake petty trading and expand Islamic education etc." $(2004,411)$. It is clear that there was more behind his intentions in Acehnese politics than merely the establishment of political alliances between Muslim states against colonial occupiers. One can try and answer the question regarding his ultimate intentions by looking at some of the other Sayyids' roles, particularly those who were a part of the Kedah court. It appears that alZāhir had political ambitions and sought to be appointed to a position in the state administration in order to acquire wealth.

What made his life unique were his extensive travels between India and Europe, and from Johor to Aceh. During his time in these places, he had many prominent roles, including that of serving as an advisor to the rulers and commanding a military unit, and involving himself in business transactions. Reid associates him essentially with the Acehnese political life, which is not untrue in the context of serving the palace and contributing to the Dutch War or, as the Acehnese know it, the Perang Sabil (Holy War), both as envoy to İstanbul and leading the war in the field. In this regard, one cannot argue that he was any different from a typical Hadhramaut who conducted business or taught in a madrasah. He spent his early life in various religious education centers. He was also a Zamindar for a Hindu ruler, while the Sultan of Johor helped him to observe British colonial rule in the reigon. He was a cosmopolitan man who had an intimate undertanding of both Eastern and Western cultures that can be readily attributed to his extensive travels.

Though he thought of himself as a 'sayyid', he abandoned the struggle for independence and eventually retired to Arabia as a politician on the basis of his agreement with the Dutch rulers. Just a few years later, the 
active struggle for independence was revived under the new leadership of the ulama in Aceh. These later struggles were far more detrimental to the financial and political resources of the Dutch colonial rule. They also caused difficulties in the Hague, the capital city of the Dutch Kingdom.

While it remains unclear what exactly forced him to surrender to the Dutch in 1878, it is well known that he often travelled between Penang and Aceh, and, towards the end of his life, he came to Aceh in 1878. After his friend and funder Teuku Payah was martyred, he surrendered to the Dutch authorities. ${ }^{42}$

Al-Zāhir appears to have been politically savy, although not fully cognizant of the nature of the colonialism more generally, nor did he fully understand the true intentions of the Dutch, particularly in the archipelago. Following the London Treaty (1824), the Dutch sought to significantly expand its terriories in Sumatra. During this time, the Dutch sought more direct control of the Straits of Malacca. This resulted in the Dutch paying more attention to the security of the sea ways, trade facilities, and agricultural production centers in these areas. This led Dutch colonial rulers in Batavia to act more aggressively, often against the will of the political elite in Hague.

In this condition, it appears that al-Zāhir's decision to surrender was based on his ultimate lack of loyalty or integration to the state or people he supposedly served. That said, his desire to reach a peace agreement with the Dutch started in March 1874, just after his return from İstanbul and just after the beginning of the second stage of the war in Aceh. At this stage, despite al-Zāhir's desire to end the conflict, the Acehnese did not wish to admit defeat in the war. Instead they sought to further continue their resistence against Dutch subjugation. 


\section{Endnotes}

1. Council of Eight (Dewan Delapan) including Acehnese and some Hadhramis in Penang Island was functioning as a ministering body of the Aceh struggle against the Dutch colonial army. The members are as follow, Tunku Ibrahim, Tunku Nyah Rajah, Haji Panglima Perang Yusuf, Tunku Nyah Abu, and two Penang born Arabs, say, Syeikh Ahmad, Syeikh Qasım; and two Penang born Indians, say, Omar, Quallah Mydin (Hasjmy 1971; Woltring 1962, 730).

2. Though the name of the birthplace mentioned as 'Temir' in the translation of Reid, there must have been a spelling mistake in the original copy he quoted. The same issue is highlighted by Mobini-Kesheh (1999, 23). Instead, Tarim, mentioned among other places which are referred as the origin of places of Hadhramaut families, is a well-known town in Southern area (Guennec-Coppens 1997, 165; Ho 2006).

3. Consulaat Penang 96 (Maleisie), 2.

4. BOA, A.MKT.MHM.457.55.29.1; BOA, A.MKT.MHM.457.55.24.1. See: The name is with the stamp itself.

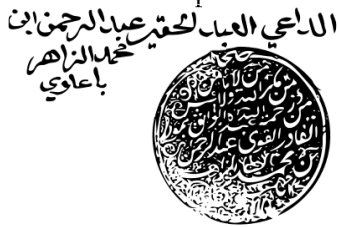

5. Ba Alawi family is observed to have been influential in Aceh through the reign of Bad'ul Alam Syarif Hasjim Jamal'ad-din al-Jamal a-Lely Ba' Alawi el-Huseyni' in the turning of the 18th century and in the first decade of the 19th century (1699-1709) (Crecelius and Beardow 1979, 64).

6. For some references see: BOA, A.MKT.MHM.457.55.18.1; BOA, A.MKT. MHM.457.55.19.1; BOA, A.MKT.MHM. 457.55.21.1; BOA, A.MKT.MHM. 457.55.22.1; BOA, A.MKT.MHM.457.55.27.1.

7. BOA, A.MKT.MHM.457.55.12.1. (Line 7). This document is the Arabic version written by the Acehnese envoy and dated on 27 Shawwāl 1289 (23 December 1872). For a similar expression See: BOA, A.MKT.MHM.457.55.16.1. (Stamp seen below is from an Arabic version of the documents.)

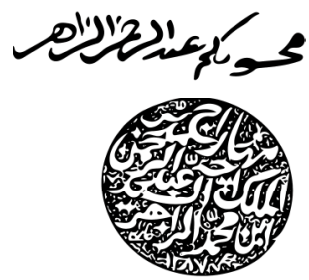

8. BOA, A.MKT.MHM.457.55.13.1. (Line 9).
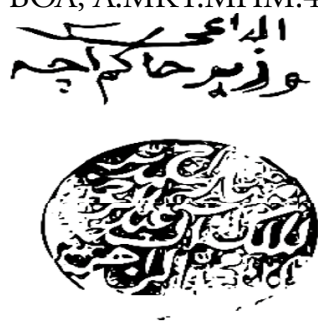
Note: His stamp, one of the total 21 stamps, is the 9th one in the first row on this document. BOA, A.MKT.MHM.457.55.21.1; BOA, A.MKT. MHM.457.55.25.1. (Note: A signature indirectly referring to 'Abd al-Rahmān al-Zāhir without mentioning his name, instead his title. See: BOA, A.MKT. MHM.457.55.30.1. "Maharaja Mudabbir al-Malik al-Sayyid 'Abd al-Raḥmān alZāhir...” A.MKT.MHM. 457.55.21.1. (This is an Arabic document).

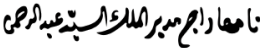

Note: Aceh and Dutch sources also refer to 'Abd al-Raḥmān al-Zāhir as "Maharaja Mudabbir'ul Malik". See: For some other examples (Bake 1873, 68; Jakub 1960, 25).

9. BOA, HR.TH.208.75 (12.3.1898).

10. BOA, A.MKT.MHM.457.55.16.1; BOA, A.MKT.MHM. 457.55.20.1. (See: The first stamp); BOA, A.MKT.MHM.457.55.17.1; BOA, A.MKT.MHM.457.55.24.1; BOA, A.MKT.MHM.457.55.26.1.

11. BOA, BEO.1145.85850.1.1; BOA, BEO.1145.85850.2.2 (21.6.1898); BOA, HR.TH.208.75 (12.3.1898).

12. BOA, HR.TO.587.26.1.3 (31.12.1889); A.MKT.MHM.457.55.18.1 and A.MKT. MHM.457.55.17.1 (8.12.1872).

13. BOA, HR.TO.587.26.1.2 (31.12.1889).

14. BOA, A.MKT.MHM.457.55.16.1.

15. See: BOA, A.MKT.MHM.457.55.17.1. (Line 21)

16. BOA, A.MKT.MHM.457.55.18.1; BOA, A.MKT.MHM.457.55.19.1; BOA, A.MKT. MHM.457.55.12.1; BOA, A.MKT.MHM.457.55.17.1.

17. Copy of a letter from Habib Abdurrahman al-Zahir ('Sajjid Abdoerrahman') to Panglima Seri Muda Perkasa (Panglima Polem), 1-3.

18. BOA, BEO.1145.85850.2.2. (Note: Al-Zāhir's arrival to Aceh was through Singapore on the basis of Reid's account. See: Reid, 1972, 46.)

19. Consulaat Penang 94.

20. This particular information collected from personal interview with an elder, named Jafaar, in Autumun, 2005, who was among the few elder people survived from the tsunami in 2004.

21. Copy of a letter from Habib Abdurrahman al-Zahir ('Sajjid Abdoerrahman') to Panglima Seri Muda Perkasa (Panglima Polem), 1.

22. BOA, BEO.1145.85850.2.2. (Note: Seyyide Aişe Hanım travelled to Aceh to meet her mother after 15 years. But she was first taken into custody in Kota Raja, later on sent to Batavia and prisoned there).

23. Potjet is not a girl's name, instead a title given to lady members in noble families. It means 'princess' in Aceh language.

24. Reid $(1972,46)$ mentions the name of the village as Kampung Langsepong. See: BOA, BEO.1145.85850.2.2.

25. BOA, BEO.1145.85850.4.1.(21.6.1898); BOA, HR. TH. 208. 74.1.1. (12.3.1898) (Line 4); BEO.1145.85850.3.1.(21.6.1898) (Line 6); BEO. 1145.85850.2.2. (Line 3)

26. BOA, BEO.1145.85850.1316.1; BOA, BEO.1145.85850.3.1; BOA, BEO. 1145. 85850.2.2.

27. BOA, BEO.1145.85850.2.2; BOA, HR.TR.208.74.1.1.

28. "Padang, 17 April", Nieuw Bataviaasch Handelsblad, Zaturdag 11 Mei 1872, No. 19, 372; "Expeditien", Nieuw Bataviaasch Handelsblad, Zaturdag 28 September 1872, No. 38, 723; "Batavia (23 November 1872)", Nieuw Bataviaasch Handelsblad, Zaturdag 28 
September 1872, No. 38, 922.

29. While serving as the head of the Baiturrahman Mosque in Banda Aceh, al-Zāhir collected significant funds to renovate this historical mosque. Other writers have commented: "The dreaded Habib Abdurrahman was only hard-working to replace the new mosque that had become ruinous with a new mosque (a simple wooden building), shortly before we arrived in Aceh" (Gobée and Adriaanse 1965, 173; Lulofs 1954, 58).

30. BOA, İ.HR.66.3208.1.1 (29.B.1266 / 10.06.1850); BOA, BEO.1145.85850.2.2; BOA, HR.TO.187.47.2.3; BOA, A.MKT.UM.25.72.1.1. (18.8.1850); BOA, HR.TO.587.26.1.1. (31.12.1889); Saffet Bey, 1329 / 1911, p. 605.

31. BOA, A.MKT.MHM.457.55.13.1.

32. For the number of stamps in a letter submitted to the governor of Mecca. See: BOA, A.MKT.MHM. 457.55.20.1.

33. For instance, while the name of Teungku Tiro is prioritized, al-Zāhir is not referred pertaining to the war against the Dutch (Ali 1970, 20; Hasjmy 1971, 44).

34. For instance, Cut Nya Dhien, Cut Meutia, Teuku Omar Johan, Teungku Chik Di Tiro were already accepted as national pablawan.

35. Copy of a letter from Habib Abdurrahman al-Zahir ('Sajjid Abdoerrahman') to Panglima Seri Muda Perkasa (Panglima Polem), 2.

36. BOA, A.MKT.MHM.475.55.13.1; A.MKT.MHM.457.55.18.1. (Note: There is also a reference that during the reign of Sultan Mansur Syah, in particular, in 1859, there was an attempt to even reach Italy to negotiate a sort of alliance against the cause of the Dutch aggression). See: "Al Hawadis al Harijiyya: Açin", Al-Jawaib, 7 Sha'ban 1290, 3.

37. BOA, A.MKT.MHM.457.55. (29 June 1873).

38. BOA, İ.HR.260.15583.

39. BOA, BEO.1145.85850.2.2.

40. BOA, BEO.1145.85850.2.2.

41. BOA, BEO.1145.85850.4.1.

42. “Teuku Payah was again severely wounded”. See: Consulaat Penang 35, 2/3 November $1876,320$.

\section{Bibliography}

\section{Arhival Sources}

Consulaat Penang 35, Telegram Book From 2nd June 1873 to 30rd August 1878, National Archive of the Netherlands, Algemeen Rijksarchif, Tweede Afdeling

Consulaat Penang 94 (Maleisie), National Archive of the Netherlands, Den Haag. (From Seyd Jafar, Rajah of ... Rajah to Mr. Paddag, after Company", Algemeen Rijksarchif, Tweede Afdelin).

Consulaat Penang 96 (Maleisie), National Archive of the Netherlands, Den Haag.

Copy of a letter from Habib Abdurrahman al-Zahir ('Sajjid Abdoerrahman') to Panglima Seri Muda Perkasa (Panglima Polem) Ronkel, Philippus Samuel van, 1870-1954. (1294 H. [1877] Or. 7249), Leiden University, Special Collections.

BOA: Başkanlık Osmanlı Arşivi 
A.MKT.MHM.457.55.

1145.85850 .

HR.TH.208.74.1.1.

HR.TH.208.75.

HR.TO.187.47.2.3.

HR.TO.587.26.1.1.

İ.HR.66.3208.1.1

İ.HR.260.15583.

Historical Notes of Singapore, History of Telok Belanggah, PA. 1741/(107) 7 September, 1976, Bil. (17), dlm. ANM. CS. 631/2/1-11 (JB), Johor Archive.

7 Numaralı Mühimme Defteri (975-976/1567-1569). (1998). ÖzetTranskripsiyon-İndeks, I, Divanı Hümayun Sicilleri Dizisi: V, T.C. Başbakanlık Devlet Arşivleri Genel Müdürlüğü Osmanlı Arşivi Daire Bakanlığı, Yayın Nu: 37, Ankara.

\section{Newspapers}

"Foreign Affairs: Holland", Al-Jawaib, 10 Rabí al-Akhir 1290, (7 May 1873), Arba'ah, Sene 13, No, 636,

"The situations of the Kingdom of Açin", Al-Jawaib, 17 Rabí' al-Awwal, 1290, (14 May 1873), Arba'ah, Sene 13, No. 637.

“Al Hawadis al Harijiyya: Açin”, Al-Jawaib, 7 Sha'ban 1290 (29 September 1873), Ithnayn, Sene 13, No. 661.

Basiret, 9 Rabī al-Akhir 1290 (05.06.1873), No. 945, Çarşamba, Yil 4.

Basiret, 20 Rabī‘ al-Awwal 1290 (18.05.1873), No. 930, Cumartesi, Yil 4.

Basiret, 11 Rabī‘ al-Akhir 1290 (07.06.1873), No. 947, Cuma, Y1l 4.

Basiret, 15 Rabī al-Akhir 1290, (11.06.1873), No. 950, Salı, Yıl 4.

Basiret, 17 Rabī‘ al-Akhir 1290, (13.06.1873), No. 952, Perşembe, Yıl 4.

Basiret, 8 Rabī‘ al-Awwal 1291(25.04.1874), No. 1214, Cumartesi, Yil 5.

"Batavia (23 November 1872)", Nieuw Bataviaasch Handelsblad, Zaturdag 28 September 1872, No. 38.

"Expeditien”, Nieuw Bataviaasch Handelsblad, Zaturdag 28 September 1872, No. 38.

"Hindia-Nederland: Negri Atjeh", Soerat Kabar Betawi, No. 23, Rebo 21 Maart, 1877. 
"Items from the Java Papers", The Straits Times, 19 June 1875.

"Java Items", The Straits Times, 27 May 1876.

“Java Items”, The Straits Times, 3 June 1876.

"Acheen Affairs", Straits Observer, 20 June 1876.

"Java Items", The Straits Times, 24 June 1876.

"Jawa Items", The Straits Times, 16 December 1876.

“Java Items”, The Straits Times, 30 December 1876.

"Netherlands Indian News", The Straits Times, Weekly Issue, Vol. XLI, Saturday, 26 December 1885, No. 3346, Singapore.

"Netherlands India News", The Straits Times, 20 August 1885.

"Netherlands Indian News". 1885. The Straits Times, Weekly Issue, Saturday, April 11, Singapore.

"Padang, 17 April”, Nieuw Bataviaasch Handelsblad, Zaturdag 11 Mei 1872, No. 19.

Straits Government Gazette, "Order of Her Majesty in council for the Regulation of Consular jurisdiction in the Dominions of Sublime Ottoman Porte", Friday 17 April 1863, No. 16, Vol. VI. (157-180).

"The Acheen War". (1885). The Straits Times, Weekly Issue, Vol. XLI, Saturday, December 5, No. 3343, Singapore.

"The Acheen War". (1885). The Straits Times, Weekly Issue, Vol. XLI, Saturday, December 26, No. 3346, Singapore.

\section{Books and Articles}

Ali, Mukti. 1970. An Introduction to the Government of Acheh's Sultanate. Yogyakarta: Jajasan Nida.

Alof. 1873. Atchin En de Atchinezeen, Een Volksboekje. Kampen: K. Van Hulst.

Bake, R.W.J.C. De Menthon. 1873. Brieven Aan Den Minister Van Buitenlandsche Zaken Te's Gravenhage over Djeddah En Atchin.

Brugmans, H. 1930. XVI Nederlandsche Historische Bibliotheek. Amsterdam: Geschiedenis Van Nederlandsch-Indie, Uitgegeven te Amsterdam Door J. M. Meulenhoff.

Chaniago, J.R. 2002. Perlawanan Tokoh Tokoh Masyarakat Aceh Terhadap Rezim Kolonial Belanda. Jakarta: ANRI.

Chauvel, Richard. 1990. Nationalists, Soldiers and Separatist: The Ambonese Islands From Colonialism to Revolt 1880-1950. Leiden: KITLV Press. 
Crecelius, Daniel, and E. A. Beardow. 1979. "A Rebuted Acehnese Sarakata of the Jamal Al-Lail Dynasty." Journal of the Malaysian Branch of the Royal Asiatic Society 52(2 (236)): 51-66.

Gobée, E., and C. Adriaanse, eds. 1965. 3 Vols. Ambtelijke Adviezen van C. Snouck Hurgronje 1889-1936. Martinus Nijhoff.

Guennec-Coppens, Françoise Le. 1997. "Changing Patterns of Hadhrami Migration and Social Integration in East Africa." In Hadhrami Traders, Scholars and Statesmen in the Indian Ocean, 1750s to 1960s, eds. Ulrike Freitag and William G. Clarence-Smith. Brill.

Hasjmy, Ali. 1971. Hikayat Prang Sabi Mendjiwai Perang Atjeh Lawan Belanda. Banda Aceh: Firma Pustaka Faraby.

1978. Bunga Rampai Revolusi dari Tanah Aceh. Jakarta: Bulan Bintang.

Hassan, Sharifah Zaleha Syed. 2004. "History and the Indigenization of the Arabs in Kedah, Malaysia." Asian Journal of Social Science 32: 401-24.

Hill, A. H. 1955. "The Hikayat Abdullah." Journal of the Malayan Branch of the Royal Asiatic Society 28(3 (171)): 3-354.

Ho, Engseng. 2006. The Graves of Tarim: Genealogy and Mobility Across the Indian Ocean. Berkeley: University of California Press.

Hurgronje, C. Snouck (Christiaan Snouck). 1906. The Achehnese. Leiden: E.J. Brill.

Jakub, Ismail. 1960. Teungku Chik Di Tiro (Muhammad Saman) Palawan Besar Dalam Perang Aceh (1881-1891). Jakarta: Bulan Bintang.

Kepper, George. 1874. De Oorlog Tuscchen Nederland En Atchin. Rotterdam: Nijgh \& Van Ditmar.

Landau, Jacob M. 1992. The Politics of Pan-Islam: Ideology and Organization. Oxford: Clarendon Press.

Lee, Dwight E. 1942. "The Origins of Pan-Islamism." The American Historical Review 47(2): 278-87.

Loethfy, Emhas. 1947. "Pahlawan Kemerdekaan Islam.” Pablawan 7(1): 15-16.

Lulofs, M. H. Szekely. 1954. Tjoet Nja Din: Riwajat Hidup Seorang Puteri Atjeh. Jakarta: Penerbit Chailan Sjamsoe.

Mandal, Sumit K. 2013. "The Indian Ocean in a Malay Text: The Hikayat Mareskalek in Transregional Perspective." Indonesia and the Malay World 41(1): 237-54.

Meriç, Ümit, Fahrettin Yahşi, Temel Hazıroğlu, and Ravza Kızıltuğ. 2010. Seyyahların aynasında şehirlerin Sultanı İstanbul. Istanbul: Albaraka Türk.

Mobini-Kesheh, Natalie. 1999. The Hadrami Awakening: Community and Identity 
in the Netherlands East Indies, 1900-1942. New York: Cornell University.

Moeis, Abdoel and Lulofs, M. H. Szekely. 1954. "Pendahuluan." In Tjoet Nja Din: Riwajat Hidup Seorang Puteri Atjeh, Jakarta: Penerbit Chailan Sjamsoe.

Mutyara. 1947. "Leboernja Kraton Atjeh.” Pahlawan 8(1): 18-19.

Paulus, J. 1917. “Encyclopaedie van Nederlandsch-Indie.” Eerste Deel A-G.

Reid, Anthony. 1969. "Indonesian Diplomacy A Documentary Study of Atjehnese Foreign Policy In The Reign of Sultan Mahmud, 1870_4." Journal of the Malaysian Branch of the Royal Asiatic Society 42(2 (216)): 74-114. $37-59$.

Roff, William R. 1985. "Islam Obscured? Some Reflections on Studies of Islam and Society in Southeast Asia." Archipel 29(1): 7-34.

Schmidt, Jan. 1992. Through the Legation Window, 1876-1926: Four Essays on Dutch, Dutch-Indian, and Ottoman History. İstanbul: Nederlands HistorischArhaeologisch Instituut Te İstanbul.

Schütz, Raymund. 2010. Moedwil En Misverstand, De Ballingschap van Habib Abdul Rachmann. History Department Leiden University. Paper archival science.

Simon, Gottfried. 1912. The Progress and Arrest of Islam in Sumatra. London: Marshall Brothers.

Tarling, Nicholas. 1957. "British Policy in the Malay Peninsula and Archipelago 1824-1871." Journal of the Malayan Branch of the Royal Asiatic Society 30(3 (179)): 3-228.

Veer, Paul Van't. 1977. Perang Belanda Di Aceh. Banda Aceh: Dinas Pendidikan dan Kebudayaan Aceh.

Vink, J.A. 1985. Sejarah Hidup: Teuku Panglima Maharaja Tibang Muhamad. Banda Aceh: Pusat Dokumentasi dan Informasi Aceh.

Wilkerson, Margaret B. 1990. "Excavating Our History: The Importance of Biographies of Women of Color." Black American Literature Forum 24(1): 73-84.

Woltring, J. 1962. Bescheiden Betreffende De Buitenlandse Politiek van Nederland, 1848-1919. 'S-Gravenhage Verkrijgbaar Bij: Martinus Nijhoff.

Mehmet Özay, School of Humanities and Social Science, Ibn Haldun University, Turkey. Email: mehmedozay@gmail.com. 


\section{Guidelines}

\section{Submission of Articles}

tudia Islamika, published three times a year since 1994, is a bilingual (English and Arabic), peer-reviewed journal, and specializes in Indonesian Islamic studies in particular and Southeast Asian Islamic studies in general. The aim is to provide readers with a better understanding of Indonesia and Southeast Asia's Muslim history and present developments through the publication of articles, research reports, and book reviews.

The journal invites scholars and experts working in all disciplines in the humanities and social sciences pertaining to Islam or Muslim societies. Articles should be original, research-based, unpublished and not under review for possible publication in other journals. All submitted papers are subject to review of the editors, editorial board, and blind reviewers. Submissions that violate our guidelines on formatting or length will be rejected without review.

Articles should be written in American English between approximately 10.000-15.000 words including text, all tables and figures, notes, references, and appendices intended for publication. All submission must include 150 words abstract and 5 keywords. Quotations, passages, and words in local or foreign languages should 
be translated into English. Studia Islamika accepts only electronic submissions. All manuscripts should be sent in Ms. Word to: http:// journal.uinjkt.ac.id/index.php/studia-islamika.

All notes must appear in the text as citations. A citation usually requires only the last name of the author(s), year of publication, and (sometimes) page numbers. For example: (Hefner 2009a, 45; Geertz 1966, 114). Explanatory footnotes may be included but should not be used for simple citations. All works cited must appear in the reference list at the end of the article. In matter of bibliographical style, Studia Islamika follows the American Political Science Association (APSA) manual style, such as below:

1. Hefner, Robert. 2009a. "Introduction: The Political Cultures of Islamic Education in Southeast Asia," in Making Modern Muslims: The Politics of Islamic Education in Southeast Asia, ed. Robert Hefner, Honolulu: University of Hawai'i Press.

2. Booth, Anne. 1988. "Living Standards and the Distribution of Income in Colonial Indonesia: A Review of the Evidence." Journal of Southeast Asian Studies 19(2): 310-34.

3. Feener, Michael R., and Mark E. Cammack, eds. 2007. Islamic Law in Contemporary Indonesia: Ideas and Institutions. Cambridge: Islamic Legal Studies Program.

4. Wahid, Din. 2014. Nurturing Salafi Manhaj: A Study of Salafi Pesantrens in Contemporary Indonesia. PhD dissertation. Utrecht University.

5. Utriza, Ayang. 2008. "Mencari Model Kerukunan Antaragama." Kompas. March 19: 59.

6. Ms. Undhang-Undhang Banten, L.Or.5598, Leiden University.

7. Interview with K.H. Sahal Mahfudz, Kajen, Pati, June $11^{\text {th }}$, 2007.

Arabic romanization should be written as follows:

Letters: ', $b, t, t h, j, h, k h, d, d h, r, z, s, s h, s, d, t, z, ', g h, f, q, l$, $m, n, h, w, y$. Short vowels: $a, i, u$. long vowels: $\bar{a}, \overline{\mathrm{i}}, \overline{\mathrm{u}}$. Diphthongs: $a w$, ay. Tà marbūtāa: t. Article: al-. For detail information on Arabic Romanization, please refer the transliteration system of the Library of Congress (LC) Guidelines. 
ستوديا إسلاميكا (ISSN 0215-0492; E-ISSN: 2355-6145) مجلة علمية دولية محكمة تصدر عن مركز دراسات الإسلام والمجتمع (PPIM) بجامعة شريف هداية الله الإسلامية الحكومية بجاكرتا، تعنى بدراسة الإسلام في إندونيسيا خاصة وفي جنوب شرقي آسيا عامة. وتستهدف المجلة نشر البحوث العلمية الأصيلة والقضايا المعاصرة حول الموضوع، كما ترحب بإسهامات الباحثين أصحاب التخصصات ذات الصلة. وتخضع جميع الأبحاث المقدمة للمجلة للتحكيم من قبل لجنة مختصة.

تم اعتماد ستوديا إسلاميكا من قبل وزارة البحوث والتكنولوجيا والتعليم العالي بجمهورية إندونيسيا باعتبارها دورية علمية (رقم القرار: 32a/E/KPT/2017).

ستوديا إسلاميكا عضو في CrossRef (الإحالات الثابتة في الأدبيات الأكاديمية) منذ ع ا • ب، وبالتالي فإن جميع المقالات التي نشرتا مرقمة حسب معرّف الوثيقة الرقمية (DOI). ستوديا إسلاميكا بجلة مفهرسة في سكوبس (Scopus) منذ .ب مايو 0 . ب.

$$
\begin{aligned}
& \text { قيمة الاشتر الك السنوي خارج إندونيسيا: }
\end{aligned}
$$

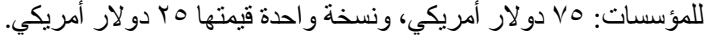

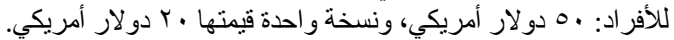

$$
\begin{aligned}
& \text { والقيمة لا تشمل نفقة الإرسال بالبريد الجوي. ونسي. }
\end{aligned}
$$

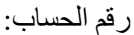

$$
\begin{aligned}
& \text { خارج إندونيسيا (دولار أمريكي): ابن }
\end{aligned}
$$

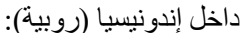

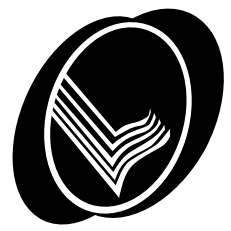




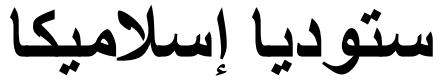 \\ مجلة إندونيسيا للار اسات الإسلامية العية

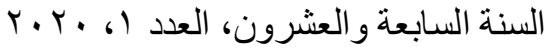

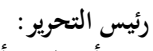

$$
\begin{aligned}
& \text { أزيوماردي أزرا }
\end{aligned}
$$

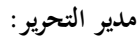

$$
\begin{aligned}
& \text { أومان فتح الرحمن } \\
& \text { هيئة التحرير: - ميف } \\
& \text { سيف المزاني }
\end{aligned}
$$

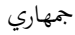

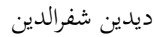

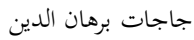

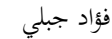

$$
\begin{aligned}
& \text { علي منحنف }
\end{aligned}
$$

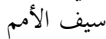

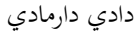

$$
\begin{aligned}
& \text { جاجانج جهراني } \\
& \text { دين واحد }
\end{aligned}
$$

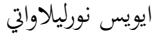

$$
\begin{aligned}
& \text { محمد قريش شهاب (جامعة شرئ شريف هداية الله الإسلامية الحكومية بجاكرتا) } \\
& \text { مارتين فان برونيسين (جامعة أتريخة) }
\end{aligned}
$$

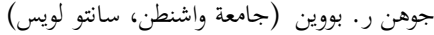

$$
\begin{aligned}
& \text { محمد كمال حسن (الجامعة الإسلامية العالمية - ماليزيا) } \\
& \text { فركنيا م. هوكير (جامعة أستراليا الحكومية كانبيرا) }
\end{aligned}
$$

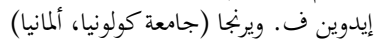

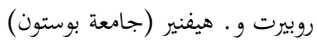

$$
\begin{aligned}
& \text { ريمي مادينير (المركز القومي للبحث (جامعة العلمي بفرن) فينسا) }
\end{aligned}
$$

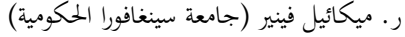

$$
\begin{aligned}
& \text { ميكائيل ف. لفان (جامعة فرينشتون) }
\end{aligned}
$$

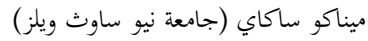

$$
\begin{aligned}
& \text { انابيل تيه جالوب (المكتبة البريطانية) } \\
& \text { شفاعة المرزانة (جامعة سونان كاليجاغا الإسلامية الحكومية) }
\end{aligned}
$$

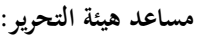

$$
\begin{aligned}
& \text { تيستريونو } \\
& \text { محمد نداء فضلان } \\
& \text { رنغكا إيكا سافوترا } \\
& \text { عبد الله مولاني } \\
& \text { مراجعة اللغة الإنجليزية: - مانية } \\
& \text { بنيمن ج. فريمان } \\
& \text { دانيل فتريون } \\
& \text { موسى بتول } \\
& \text { توباغوس أدي أسناوي }
\end{aligned}
$$

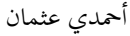





\section{لالتوايا السال|مسيا}


\إI|
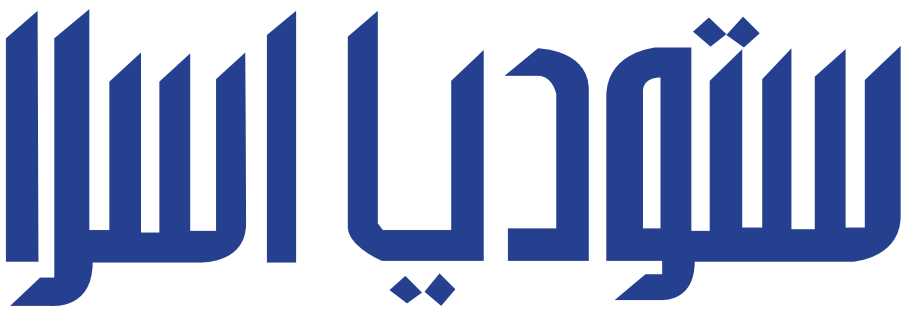

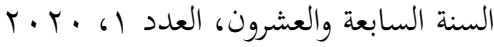

بحلة إندونيسية للدراسات الإسلامية

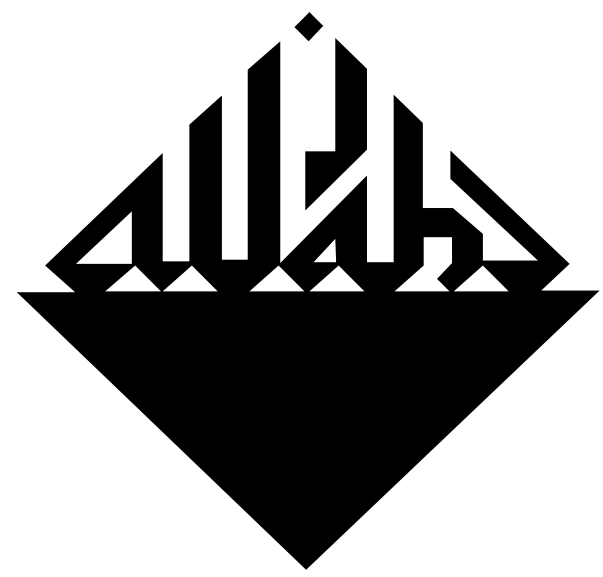

\section{اللرسم العثمانيه}

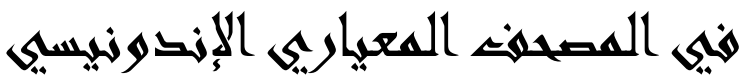

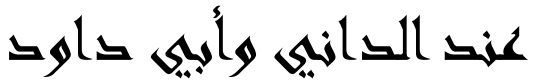

زين العارفين مذكور

\section{التمرتعائ بين السزة والشيعة}

هيك هالوكر الشمالية: قروس هن الماضيى

محمد أمين نور الدين وهيردي شاه رشاد وسميث الحضر الحرالير 